\title{
Labour mobility in marine fisheries sector: A case study from Odisha State, eastern India
}

\author{
S. S. RAJU, SHYAM S. SALIM*, PHALGUNI PATTNAIK AND A. M. SHINU* \\ Regional Centre of ICAR-Central Marine Fisheries Research Institute, Pandurangapuram, Visakhapatnam - 530003 \\ Andhra Pradesh, India \\ "ICAR-Central Marine Fisheries Research Institute, Ernakulam North P. O., Kochi-682 018, India \\ e-mail:ss.raju@icar.gov.in
}

\begin{abstract}
This paper presents an insight into the mobility of the marine fishers of Pentakota area of Puri District of Odisha, migrated from various parts of Andhra Pradesh in search of sustainable livelihood and better socio-economic conditions. The study relied on primary data collected from 147 migrant fishermen households selected through random sampling method. The study attempts to examine the pros and cons of labour mobility in the marine fisheries sector. Analysis on the socio-economic profile of the migrant fishers revealed that $64 \%$ of migrant populations are in the age group 31-50 years and most of them belong to Christian and Hindu religions and $87 \%$ of them are from other backward castes (OBC). The prime reasons for migration included low income, debts and financial commitments and disguised unemployment. The analysis indicated that consequent to migration, the fishers augmented their income besides increased savings, construction of house and possession of personal assets along with an elevation to their social status. The expenditure pattern of the migrants including clothing, shelter, food and education of dependents were also analysed. The major problems confronted during migration are language barrier, cultural lag and conflicts with established migrant labourers. Even though the labour mobility has contributed much to the marine fishery economy of the region, the ecological and social changes might impact occasional conflict between the migrants and native fishers for the scarce marine fishery resources. Hence, sufficient steps have to be taken for skill development and improvement of socio-economic conditions of the migrant fishers as well as for better management of conflicts among fishers.
\end{abstract}

Keywords: Andhra Pradesh, Labour, Marine Fisheries, Migration, Odisha

\section{Introduction}

Migration is a worldwide phenomena that is defined as the movement of people from less endowed to more endowed resource areas in search of better income, employment, food and better socio-economic conditions (Belton et al., 2013; Shyam et al., 2021a). Labor migration, which is defined as the cross-border movement of workers for the purpose of employment, has become an increasingly essential characteristic of the globe, causing a slew of economic, social and political issues. Inequality of income, climate change, demographic shifts, and conflicts all had a role in the movement of workers in search of work and stability. Various research has recently depicted migration as an adaptive or coping mechanism that is gaining recognition. Migrant workers contribute to the growth and development of the host area, while remittances benefit their native place. Globally, fishing communities' livelihoods and way of life are in jeopardy as they battle to cope with declining fish sources and a growing regulatory framework (Urquhart et al., 2013). The dire straits of coastal fishermen mainly poverty, indebtedness and income inequalities lead the fishermen to migrate from their native place to other places for better living conditions (Shyam et al., 2017). The movement of fishermen has influenced the repercussions on the economies of both the native and host areas (Shyam et al., 2021b).

Marine fisheries, as one of the country's most important sectors, contributes significantly to food security and employs approximately 1.5 million people directly (DoF, 2021), as well as numerous indirect dependents in the primary, secondary, and tertiary sectors are involved with fishing. Nonetheless, disguised unemployment (a condition in which people appear to be working but are forced to labour less than their potential) is widespread in the country, prompting fishermen to migrate to areas with superior resources and earning potential. According to Shyam et al. (2013), the fishermen in India are undergoing a shift in terms of social security measures, as seen by improvements in literacy levels, health profiles, income, and participation in many alternative occupations. Studies on fishermen migration have been outlined by several authors mostly based on socio-economic perspective 
with emphasis on the nature and problems related to this (McDowell and De Haan, 1997; Kothari, 2002; Sathiadhas and Sangeetha, 2009; Swathilekshmi et al., 2011; George, 2013; Swathilekshmi and Johnson, 2013; Dhas and Sundararaj, 2014).

Odisha, a state in eastern India on the Bay of Bengal's coast, is a major fish-producing marine state that ranks fourth in total fish output behind Andhra Pradesh, West Bengal and Gujarat. Odisha has established itself as one of the country's leading fish producers. There are 10,826 crafts in the sector of which 2,248 are mechanised, 3,922 motorised and the rest are non- motorised. Trawlers (58\%), gillnetters (35\%), longliners (5\%) and bagnetters $(2 \%)$ are the main crafts in the mechanised sector (Ngasotter et al., 2020). The fishermen population of the state is about 12.6 lakhs (Kumari, 2014). For three months a year, Oriya fishermen living around $15 \mathrm{~km}$ upstream from the mouth of the river Debi between Puri and Jagatsinghpur districts migrate downstream to the sea shore and conduct fishing from the beaches and use the small pelagics caught during this period for drying purpose (Sarma and Salagrama, 2007).

Marine fishing in Odisha is dominated by settlers from other areas such as Andhra Pradesh, West Bengal and Bangladesh. Permanent settlement of the migrant labourers from these areas has been occurring since 1950s. The organisation and management systems developed by these permanent settlers are commendable and are accepted by the local community. Several migrants consider themselves as full-fledged Odisha residents; still have relations with their native place. The thriving fishing village of Pentakota in the heart of Puri District of Odisha stands important to the migrant fishers from Andhra Pradesh.

Migration is predominantly from rural areas to urban areas. The significant cause of the migration is to look for preferable employment. Lower wage rate in the native place leads the people to migrate (Keshri and Bhagat, 2013; Tilak and Kingsukmaity, 2018). Labourers from the traditional sector moves to modern fishing technologies (Sathiadas and Sangeetha, 2009). This paper presents an insight into the mobility of the marine fishers from different parts of Andhra Pradesh to Pentakota area of Puri District in Odisha in search of sustainable livelihood and improved socio-economic conditions. The goal of the study was to look at the benefits and drawbacks of labour mobility in the marine fisheries sector. The empirical evidence offered in the research examines the pattern of income and savings, reasons for and challenges with migration, as well as the migrants' socioeconomic circumstances.

\section{Materials and methods}

The research was carried out using primary data gathered from migratory fisherman of Andhra Pradesh at Pentakota area of Puri District in the state of Odisha, selected through random sampling method. A sample of 147 migrant workers was personally interviewed using a pre-tested interview schedule. The data collected includes the personal details, educational status, income and savings, indebtedness, consumption and expenditure pattern, reasons for and problems of migration. Descriptive statistical analysis and Garrett ranking technique were employed for the analysis.

The respondents' preferences on different reasons and constraints due to migration were ranked using Garrett's ranking technique. The migrants were asked to list the reasons/constraints that were important to them on a scale of one to nine. The scores were calculated using the ranks given by each migrant. The scores of individual migrants were then summed together and divided by the total number of respondents for each reason/constraint. The mean scores for all of the reasons/ constraints were ranked and arranged in descending order. The accuracy in determining the preference was attained using this method. The components with the highest mean value or Garrett score are considered the most important factor.

The ranks allocated by the migrants were converted into scores using the following formula:

$$
\% \text { Position }=\left(100\left(\mathrm{R}_{\mathrm{ij}}-0.5\right) / \mathrm{N}_{\mathrm{i}}\right.
$$

where, $\mathrm{R}_{\mathrm{ij}}=$ Rank given for $\mathrm{i}^{\text {th }}$ items by the $\mathrm{j}^{\text {th }}$ individual; $\mathrm{Nj}=$ Number of items ranked by $\mathrm{j}^{\text {th }}$ individual

The $\%$ position of each rank was thus acquired, which was then transformed into scores using Garrett and Woodworth's table (1969).

\section{Results and discussion}

\section{Socio-economic characteristics}

The important conclusions about the socio-economic features of the respondents are presented in Table 1 . From Table 1, it could be observed that most of the respondents are from the age range of 40 to 60 years constituting $53 \%$ of the total respondents. About $43 \%$ belong to 20 to 40 years age group while only a $4 \%$ are found aged above 60 years. In an earlier study on migration patterns in marine fisheries sector of Gujarat and Maharashtra, Shyam et al. (2021a) reported the bulk of responders are between the ages of 20 and 40, accounting for $77 \%$ in Gujarat and $86 \%$ in Maharashtra. 
Table 1. Socio-economic characteristics of the migrants

\begin{tabular}{|c|c|c|c|c|c|c|c|c|}
\hline \multicolumn{2}{|c|}{ Age dispersal (Years) } & \multicolumn{3}{|c|}{ Literacy level (\%) } & \multicolumn{2}{|c|}{$\begin{array}{l}\text { Income Status } \\
\text { (₹ } 000 \text { per month) }\end{array}$} & \multicolumn{2}{|c|}{ Skills related to fishing } \\
\hline Age range & Frequency & Grade & Head of Family & Family & Amount & Frequency & Skill & Frequency \\
\hline $20-40$ & $63(43)$ & Illiterate & 79.59 & 61.77 & $<10$ & $1(0.68)$ & Business (Marketing) & $2(1.36)$ \\
\hline $40-60$ & $78(53)$ & Lower primary & 4.08 & 6.26 & $10-20$ & $141(95.92)$ & Fishing & $130(88.44)$ \\
\hline \multirow[t]{4}{*}{ More than 60} & $6(4)$ & Upper primary & 11.56 & 8.44 & $20-30$ & $4(2.72)$ & $\begin{array}{l}\text { Fishing \& Business } \\
\text { (Marketing) }\end{array}$ & $12(8.16)$ \\
\hline & & Matric/ SSLC & 0.68 & 3.67 & More than 30 & $1(0.68)$ & Fishing/Drying & $2(1.36)$ \\
\hline & & Higher secondary & 4.08 & 19.73 & & & Labour & $1(0.68)$ \\
\hline & & Degree & 0 & 0.14 & & & & \\
\hline
\end{tabular}

Figures in parentheses indicates \% to total

The educational status, indicated that, about $62 \%$ of the migrants' family members are illiterate, while a $20 \%$ acquired higher secondary education. It can be noted that $80 \%$ of the head of the families were found illiterate and a $12 \%$ were having upper primary education (Table 1 ). In a study among the migrants in Karnataka, Shyam et al. (2021b) revealed that $52 \%$ had completed high school, with $28 \%$ having completed secondary school level education.

The income status of the respondents was also analysed, which indicated that about $96 \%$ of the migrants had monthly earnings between ₹ 10,000 to ₹20,000, whereas $3.4 \%$ of the respondents earned above ₹20,000 and about $0.7 \%$ of the migrants earned below ₹ 10,000 per month (Table 1). Shyam et al. (2021b) in their study in Karnataka, reported that $67 \%$ of the respondents have income range of ₹20,000 to 30,000 followed by $23 \%$ having income less than ₹20,000.

Most of the migrants $(88 \%)$ possess skills related to fishing (Table 1), while around $8 \%$ of them possess business/marketing skills along with fishing skills. An infinitesimally small $\%$ of the respondents (1.4) were found engaged in allied activities like drying of fish.

\section{Religion and caste orientation}

The study also revealed the religion and caste orientation of the migrants as depicted in Figs. 1 and 2 respectively which indicates that $46 \%$ of migrants are Christians, while 54\% are Hindus. Most of the migrants are from other backward castes (OBCs, $87 \%$ ) and $13 \%$ are from scheduled castes (SCs).

\section{Asset ownership pattern}

The asset details of respondents are presented in Table 2. Land, house and jewellery were found to be the most valuable assets created by migrants over time, with an average asset worth ranging from one lakh to five lakh rupees (Table 2).
Table 2. Asset creation and valuation among migrants (in ₹ lakhs)

\begin{tabular}{lllll}
\hline Asset valuation & House & Land & Jewellery & Total \\
\hline Less than one & $123(84)$ & $103(91)$ & $143(99)$ & $31(21)$ \\
$1-5$ & $21(14)$ & $10(9)$ & $1(1)$ & $113(77)$ \\
$5-10$ & $3(2)$ & 0 & 0 & 0 \\
More than 10 & 0 & 0 & 0 & $3(2)$ \\
Total & 147 & 113 & 144 & 147 \\
\hline
\end{tabular}

Figures in the parentheses indicates \% to total

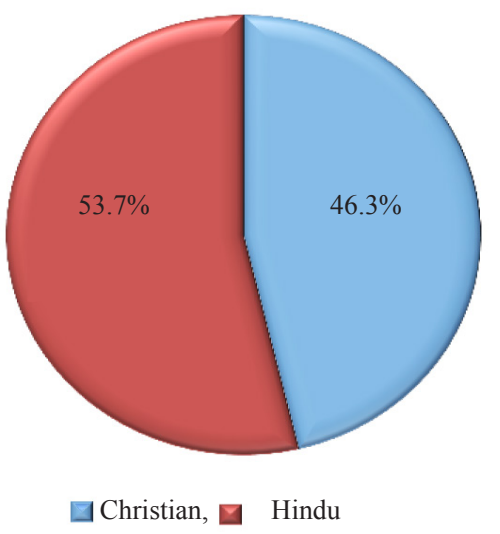

Fig. 1. Religion orientation of the respondents (\%)

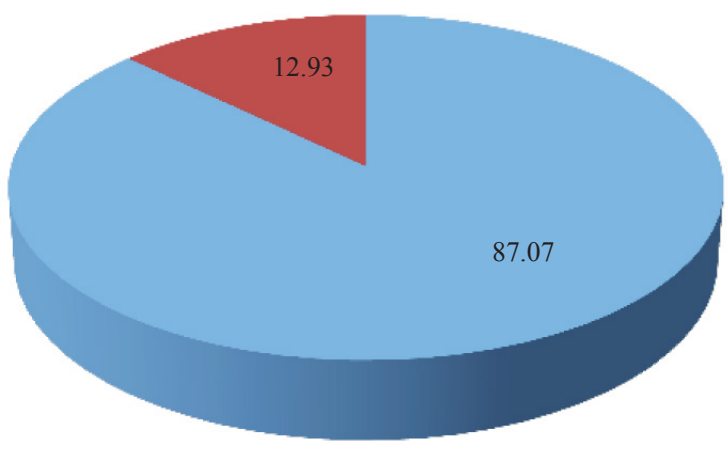

$\mathrm{OBC}, \square \mathrm{SC}$

Fig. 2. Caste orientation of the respondents (\%) 
According to a study, migrants place a higher value on to creating assets in the form of jewellery (99\%), followed by acquiring land (91\%) and house (84\%). All the migrants own house and around $84 \%$ among them own house valuing less than rupees one lakh. Nearly $99 \%$ of the respondents are possessing jewels valuing less than rupees one lakh. Around 1\% of the migrants are having jewels worth of rupees one lakh to five lakhs. Around 9\% of the migrants are having land valuing between ₹1-5 lakhs and $91 \%$ of the migrants are possessing land valuing less than ₹1 lakh. The study shows that $77 \%$ of the migrants possess various assets valued between ₹1 lakh and 5 lakhs, which indicates the comparative well off position of the respondents. Shyam et al. (2017) based on their study in Kerala observed that migrants place a higher value on housing creation than on other assets. Land is considered to be the migrants' second most valuable possession.

\section{Indebtedness and repayment}

The study looked at the financial obligations of migrant employees and showed that, in comparison to their native, the bulk of them have very little debt in Pentakota. Fig. 3 shows the details of migrant workers' indebtedness levels.

It could be found that $79 \%$ of the migrants do not have any financial obligations. Only $16 \%$ of those surveyed have financial obligations below ₹6 lakhs, whereas $1 \%$ having a liability amounting between ₹6 and 12 lakhs and $4 \%$ is having a liability amounting to above ₹ 12 lakhs.

The details regarding the source of finance are depicted in Fig. 4 which shows that the migrant workers are depending on the private money lenders and boat

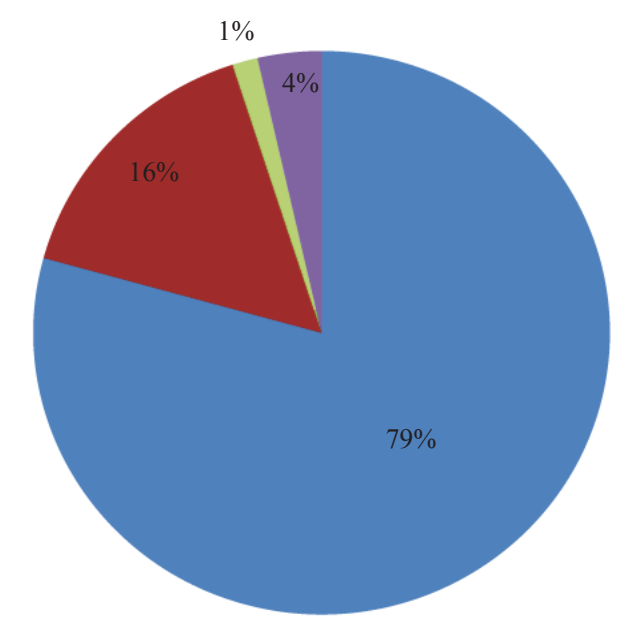

Nil, <6Lakhs, 6-12 lakhs, _ >12 lakhs

Fig. 3. Level of indebtedness of the migrants owners for small amounts (below ₹ 6 lakhs) as well as for big amounts (above ₹ 6 lakhs), while they are depending on the institutional finance like banks and cooperatives for ₹12 lakhs and above.

\section{Pattern of expenditure}

The average monthly expenditure pattern of the migrants at their native place as well as their work place were examined and results are presented in Table 3, which indicates that clothing tops the expenses (34\%) at native place while it is for food $(40 \%)$ at the work place. The average monthly expenditures at the workplace was comparatively lesser than at the native place. The major expenses at the workplace included food (40\%), clothing

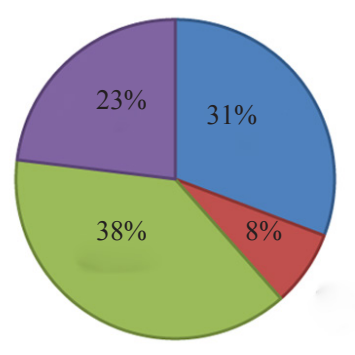

$\square$ Bank, $\square$ Cooperative, $\square$ Private money lender, $\square$ Boat owner

(a)

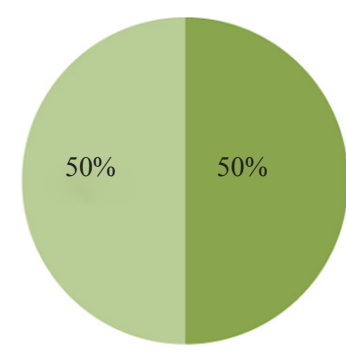

Private money lender, $\quad$ Boat owner

(b)

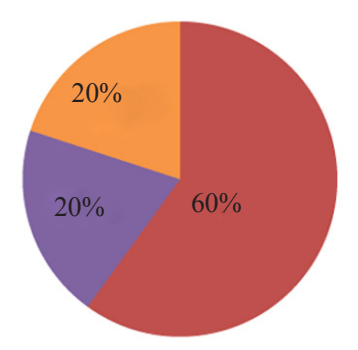

Bank, - Cooperative, _ Private money lenders

(c)

Fig. 4. Source of finance among the migrants. (a) <₹ 6 lakhs; (b) ₹ 6-12 lakhs and (c) More than ₹ 12 lakhs 
Table 3. Pattern of average monthly expenditure (₹per month)

\begin{tabular}{lll}
\hline Items & At native place & At work place \\
\hline Food & $1396(20)$ & $2644(40)$ \\
Clothing & $2388(34)$ & $1306(20)$ \\
Shelter & $701(10)$ & $305(5)$ \\
Fuel/ Electricity & $223(3)$ & $473(7)$ \\
Health care & $1748(25)$ & $1068(16)$ \\
Education & $527(8)$ & $0(0)$ \\
Social expenses & $0(0)$ & $366(6)$ \\
Others & $0(0)$ & $429(7)$ \\
Total & 6983 & 6591 \\
\hline
\end{tabular}

Figures in parenthesis indicate \% to total

$(20 \%)$, health care $(16 \%)$, fuel/electricity $(7 \%)$, social expenses $(6 \%)$ and others (7\%). An average monthly amount of ₹ 6,983 is spent at the native place while an amount of ₹ 6,591 is spent at the work place.

\section{Details of migration}

Migration is usually triggered by a variety of unpredictable circumstances. However, the major drivers of migration are regarded to be socio-political, economic, environmental and ecological factors (Shyam et al., 2021a,b).

According to the study, all the respondents had migrated with their family from Andhra Pradesh and settled in Pentakota area of Puri District in Odisha. Moreover, the study points out that the average age of migrant labourers was found to be 23.75 years from north coastal districts of Andhra Pradesh. The migration details of the respondents indicates that the respondents have migrated from three districts of Andhra Pradesh. Out of the migrated fisherfolk settled in Pentakota, approximately $50 \%$ are from Srikakulam, 30\% from Vizianagaram and 20\% from Visakhapatnam districts of Andhra Pradesh.

The reasons and constraints of the migration were analysed and the result is featured under the following heads.

\section{Reason analysis}

The migration reason analysis was based on the opinions of the migrants in the Pentakota area. The principal reasons cited by the migrants were ranked using the Garrett technique, and the ranks are shown in Table 4.

Low income, debts and financial commitments and seasonality of employment are the most common reasons for migrating, according to the respondents. Apart from this, disguised unemployment, persuasion of friends, a lack of technical knowledge, a desire to travel, and a poor level of education were also pinted out as reasons for migration. Wickramasekara (2002) as well as Shyam et al. (2021a) observed that the major reasons for migration
Table 4. Reasons for migration

\begin{tabular}{ll}
\hline Reasons & Rank \\
\hline Low income & I \\
Seasonality of employment & III \\
Debts and financial commitments & II \\
Lack of technical knowledge & VII \\
Interest towards travelling & VIII \\
Low level of literacy & IX \\
Distinguished employment at distant locations & IV \\
Influence by friends & V \\
Others & VI \\
\hline
\end{tabular}

are in search of higher incomes, influenced by friends, relatives and social networks.

\section{Constraint analysis}

The constraints that migrants experience at work were also analysed and the results obtained using the Garrett ranking technique are presented in Table 5.

Difficulty in learning local language and cultural lag of the migrants were identified as the most important constraints faced by the migrants. Another factor observed among migrants working in landing centres is competition, which causes workers to be willing to make little sacrifices in their monthly wages in order to take advantage of chances. Followed by competition, lack of experience and discrimination in terms of revenue sharing are also given countable relevance by the respondents. Inadequate skills other than fishing and lack of education are also reported as constraints. To build up the capability of the workforce, proper training programmes on the increasingly evolving fishing methods must be given (Crilly and Esteban, 2013).

Details about the migrants' remittances to their native place were also collected and displayed in Fig. 5 which reveals that almost $47 \%$ of migrants send a ₹ 1,000 remittance. About $27 \%$ of the migrants' remit between $₹ 1,501$ and 2,000, while $10.9 \%$ remits an amount up to $₹ 1,001$ and 1,500 monthly. Only $7.3 \%$ of the migrants' remit above ₹2,000 monthly. This demonstrates that migrant remittances help to support the fisherman's family

Table 5. Constraints during migration

\begin{tabular}{ll}
\hline Constraints & Rank \\
\hline Difficulty in language & I \\
Cultural lag & II \\
Lack of education & IX \\
Competition amongst migrants & III \\
Competition amongst locals & V \\
Lack of experience & IV \\
Discrimination in terms of revenue sharing & VI \\
Inadequate skills other than fishing & VIII \\
Others & VII \\
\hline
\end{tabular}




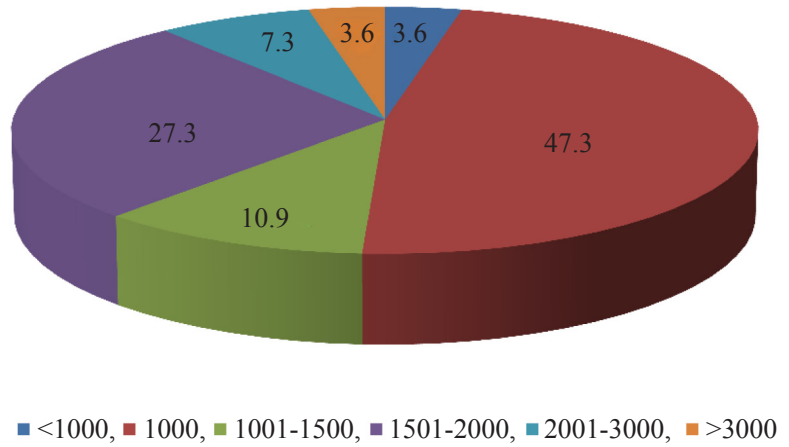

Fig. 5. Monthly remittances by the migrants to their native place (\%)

in their native place. Vertovec (2002) has recognised that migrants maintain contact with people in their places of origin through correspondence and remittances.

\section{Employment during closed season / Alternative avocations}

Migrant labourers are unemployed during the closed season and neither the owners nor the Odisha government provide relief. An insignificant portion of the migrants are departing for alternate avocations, the details of which are presented in Table 6.

During the closed season, the respondents' primary alternative occupations are based on daily wage jobs such as carpentry, masonry, painting, plumbing (13\%) followed by net mending (10\%) and boat repair (7\%). In a similar study in Kerala, Shyam et al. (2017) observed that the major alternative avocations for workers during the off-season, are paid on a daily basis, with farming, net mending, carpentry, masonry, painting and plumbing being the most common alternate occupations.

\section{Impact of migration on socio-economic status}

As perceived by the migrants, their socio-economic status has improved considerably through migration, which could be ascertained through this study. The major positive consequences are depicted in Fig. 6. The findings revealed that, about $94 \%$ of the migrants had increased their savings. About $62 \%$ of the respondents constructed/ improved their house while $43 \%$ possessed different assets.

About $38 \%$ of migrants have improved their social position and $27 \%$ are able to provide good education to

Table 6. Alternative avocations during the closed season/ban period

\begin{tabular}{ll}
\hline Activity & Frequency \\
\hline Carpentry/ Masonry/ Painting/ Plumbing & $20(13)$ \\
Boat repair & $10(07)$ \\
Net mending & $15(10)$ \\
Others & $3(02)$ \\
\hline
\end{tabular}

Figures in parenthesis indicate \% to total

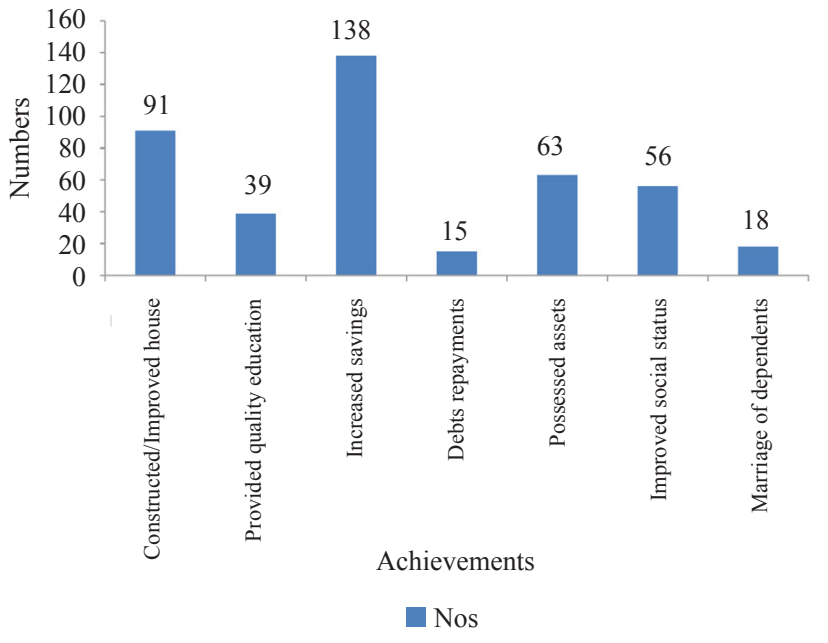

Fig. 6. Major achievements through migration (Nos.)

their children and $12 \%$ of respondents have married their dependents using the resources they have accumulated through migration. The findings highlighted the socioeconomic improvements attained by the workers through migration. The respondents opined better social and financial status consequent to migration (Posel et al., 2006; Menz and Alexander, 2010) and concluded that labour mobility resulted in peaceful life and helped to reduce financial liabilities.

Shyam et al. (2021a) also reported the positive consequences as improved quality of life (12\% in Gujarat and $13 \%$ in Maharashtra), marriage of respondents $(10 \%$ in Gujarat and 9\% in Maharashtra), improved social status ( $9 \%$ in Gujarat and 7\% in Maharashtra), possession of assets (6\% in Gujarat and 5\% in Maharashtra) and debts repayment (3\% in Gujarat and $2 \%$ in Maharashtra). Despite the fact that migrants face several challenges, the benefits they receive outweigh the disadvantages.

According to a study on labour mobility, the primary reason for labour migration is low income at home, followed by seasonality of employment, debts and financial commitments, disguised unemployment, interest in travelling, encouragement by friends, low education level, lack of technical knowledge, and other factors. The survey found that workers, regardless of their nativity, earn and save more money as a result of migration and live a pleasant life with few financial obligations. Debt repayment, house construction, and increasing savings were found to be the key accomplishments of the migrants over time. Migrant workers enhanced their social status, acquired possessions and were able to give better education to their children as a result of their migration.

The two most significant limitations observed are competition among migrants and revenue sharing 
discrimination. As a result, proper policy measures to protect the rights of migrants working onboard and at landing centres are required. Adequate skill upgradation programmes on improved fishing technologies may be organised to build the capacity of the workers.

Historical patterns of resource availability, skill empowerment and economic and political variables all impact migration. Despite the fact that labour mobility has contributed significantly to the region's marine fishery economy, ecological and social changes may result in occasional conflict between migrants and native fishers over the region's limited marine fishing resources. As a result, significant actions must be taken to improve migrant fishermen's skill development and socio-economic conditions. Adequate financial support and welfare measures are also needed to ensure their livelihood during lean/closed fishing seasons. Enabling environment for better management of conflicts between the migrants and native fishers are also the need of the hour.

\section{Acknowledgements}

The article is drawn out of project on "Supply chain management of marine fisheries sector in India" funded by ICAR-CMFRI, Kochi. We express our sincere thanks to the Director, ICAR-CMFRI and the Scientist-In-Charge, Visakhapatnam Regional Centre of ICAR-CMFRI, for providing resources for undertaking this study. We also thank the migrants to Pentakota area of Puri District in Odisha for sharing their valuable data on labour migration.

\section{References}

Belton, B., Marschke, M. and Vandergeest, P. 2013. Fisheries development, labour and working conditions on Myanmar's marine resource frontier. J. Rural Stud., 69: 204-213. https://doi.org/10.1016/j.jrurstud.2019.05.007.

Crilly, R. and Esteban, A. 2013. Small versus large-scale, multi fleet fisheries: The case for economic, social and environmental access criteria in European fisheries, Mar. Policy, 37: 20-27. https://doi.org/10.1016/j. marpol.2012.04.018.

DoF 2021. Handbook on fisheries statistics 2020, Department of Fisheries, Ministry of Fisheries, Animal Husbandry and Dairying, Govt. of India, New Delhi, India, 54 pp.

Dhas Kennedy, J. and Sundararaj, P. 2014. Determinants of fishermen migration: Study on a traditional marine fishing village in Kanyakumari District. Intl. J. Res. Mngt, Soc. Sci. Tech., 8: 8.

Garrett, H. E. and Woodworth, R. S. 1969. Statistics in psychology and education. Vakils, Feiffer and Simons Pvt. Ltd., Mumbai, India, 329 pp.

George David 2013. Constraints of out migrant fishermen Diaspora in Kanyakumari. Indian Streams Res. J., 3: 6.
Keshri, K. and Bhagat, R. B. 2013. Socioeconomic determinants of temporary labour migration in India: A regional analysis. Asian Population Stud., 9(2): 175-195. https:// doi.org/10.1080/17441730.2013.797294.

Kothari, U. 2002. Migration and chronic poverty, vol. 16. Institute for Development Policy and Management: Chronic Poverty Research Centre, Manchester, UK.

Kumari, M. K. and Patra, S. 2014. Growth and performance of fishery in Odisha. Asian J. Res. Business Econ. Manag., 4(6): 100-110.

Mc Dowell, C. and De Haan, A. 1997. Migration and sustainable livelihoods: A critical review of the literature, IDS Working Paper 65, Institute of Development Studies, University of Sussex, Brighton, Manchester, UK.

Menz, K. M. 2010. Corporate social responsibility: Is it rewarded by the corporate bond market? A critical note. J. Business Ethics, 96(1): 117-134.

Ngasotter, S., Panda, S. P., Mohanty, U., Akter, S., Mukherjee, S., Waikhom, D. and Devi, L. S. 2020. Current scenario of fisheries and aquaculture in India with special reference to Odisha: A review on its status, issues and prospects for sustainable development. Int. J. Bio-Resour. Stress Manag., 11(4): 370-380.

Posel, D., Fairburn, J. A. and Lund, F. 2006. Labour migration and households: A reconsideration of the effects of the social pension on labour supply in South Africa. Econ. Model., 23(5): 836-853.

Sarma, S. B. and Salagrama Venkatesh 2007. Migration of fishermen from Srikakulam District in Andhra Pradesh Report. South Indian Federation of Fishermen's Societies, Chennai, India.

Sathiadhas, R. and Sangeetha, Prathap, K. 2009. Employment scenario and labour migration in marine fisheries. Asian Fish. Sci., 22(2): 713-727.

Shyam S. Salim., Sathiadhas, R., Narayanakumar, R., Katiha, P. K., Krishnan, M., Biradar, R. S., Nikita Gopal, Nagesh Barik and Ganesh Kumar, B. 2013. Rural livelihood security: Assessment of fishers' social status in India, Agric. Econ. Res. Rev., 26: 21-30.

Shyam S Salim., Rahman, M. R. and Athira, N. R. 2017. Labour migration and alternate avocation in marine fisheries sector of Kerala. J. Mar. Biol. Ass. India, 59(2): 109-114.

Shyam S. Salim., Vase, V. K., Jamsji, J., Shinu, A. M., Athira, N. R. and Bhatt, B. 2021a. Assessing labour migration patterns in marine fisheries sector across the coastal states of Gujarat and Maharashtra. Indian J. Econ. Dev., 9: 1-9.

Shyam S. Salim, Sujitha Thomas and Shinu, A. M. 2021b. Assessing labour mobility in marine fishing operations in Karnataka. Int. J. Fish. Aquat. Stud., 9(2): 189-194. DOI: 10.22271/fish.2021.v9.i2c.2450.

Swathilekshmi, P. S., Dineshbabu, A. P., Mahadevaswamy H. S. and Lingappa 2011. Migrant labourers in the marine fisheries sector. Mar. Fish. Infor. Serv. T\&E Ser., 207: 26-27. 
Swathilekshmi, P. S. and Johnson, B. 2013. Migrant labourers in primary sector of marine fisheries: A case study in Karnataka, Research Centre of ICAR-Central Marine Fisheries Research Institute, Mangalore.

Urquhart, J., Acott, T. and Zhao, M. 2013. Introduction: Social and cultural impacts of marine fisheries, Mar. Policy. 37: 1-2. DOI: 10.1016/j.marpol.2012.04.007.
Vertovec, S. 2004. Cheap calls: The social glue of migrant transnationalism. Global Networks, 4(2): 219-224.https:// doi.org/10.1111/j.1471-0374.2004.00088.x.

Wickramasekara, P. 2002. Asian labour migration: Issues and challenges in an era of globalisation. International Labour Organisation, Geneva, Switzerland. 